2,300 $\mathrm{m}$ above sea-level and has excellent observing conditions. The new Observatory building has been designed to minimize the effects of high daytime termperatures, the whole building being insulated against the daytime rise in temperature (App. Optics, 2, 1; 1963).

\section{Institute of Tropical Meteorology at Poona}

AN agreement has recently been made under which the United Nations, in collaboration with the World Meteorological Organization, will provide assistance for the establishment of an Institute of 'Tropical Meteorology at Poona. The object is to establish an Institute, as part of the Indian Meteorological Department, for carrying out investigations in applied meteorology. During the period of the International Indian Ocean Expedition, the Department will also establish a Special Division at Bombay to function as an International Meteorological Centre for co-ordinating and supporting the meteorological activities of the International Indian Ocean Expedition. At the conclusion of the activitios of the Centre, the equipment and the relevant personnel will be transforred to Poona. The assistance of the United Nations Special Fund, through the World Meteorological Organization as the cxecuting agency for the project, will continue for a period of three years. Seven experts will be providod for a total period of 15 man-years in the fields of forecasting techniques, tropical cyclone analysis and prognosis, use of machine methods in meteorological analysis and prognosis, climatology, hydrologic forecasting and meteorological research. There will be a chief expert for the project, appointed for a period of three years, who will also be the chief research forecaster in the International Meteorological Centre. On the side of the Government of India the Director-General of Observatories will have the overall responsibility for the execution of the project. Seven fellowships of one-year duration each will be awarded to technical personnel of the Indian. Meteorological Department for advanced training abroad. Moteorological equipment, cloud and storm investigations equipment and an IBM 1620 electronic computor for data processing, calculating machines and photographic equipment and accessories will also be provided. In all, for this projoct, the Special Fund will contribute 873,500 dollars (U.S.) and the Indian Government about Rs. 50 lakhs.

\section{Scientific Documentation in South and South-East Asia}

UNDER the title Scientific Documentation in South and South-East Asia, the Unesco South Asia Scienco Co-operation Office, New Delhi, and the Indian National Scientific Documontation Centre, New Delhi, havo published a survey of a rogional seminar held at New Delhi during March 7-16, 1961, under the oldspices of Unesco and the Government of India (Pp. iii +47. New Delhi: Unesco South Asia Science Co-operation Office; and Indian National Scientific Documentation Centre, 1963). It includes the inaugural addresses, a brief account of the organization of the seminar, a report on the position of scientific documentation in Asian countries (covering Burma, Ceylon, India, Indonesia, Japan, Malaya, Nepal, Pakistan, the Philippines, Singapore, Taiwan and Thailand), surnmaries of the technical paper's presented, a note on co-operation, and a list of the proposals formulated for consideration. The last-montioned include a requost to be submitted by Unesco to tho International Postal Union for reduced air-mail rates for scientific periodicals, expansion of the existing exchange between documentation centres of publications and photo-reproductions, establishment of an adequate network of microfilming units, and encouragement of the manufacture within the region of the simpler types of equipment for scientific documentation. The attention of governments is directed to the importance of developing, in each country, libraries with large collections of scientific literature as an essential basis for documentation services, and to the importance of Unosco Coupons for oporating documentation services. The governments are also urged to make use of the facilities offered by the Unesco Technical Assistance and Participation Programmes and other aid programmes. Acceleration of the publication within the region of Union Catalogues, national lists of periodicals, and current National scientific bibliographies is also urged, and the importance of the exchange of scientific publications in developing scientific documentation generally is omphas. ized.

\section{Recommendations for Letter Symbols, Signs and Abbreviations}

PART 6 of the British Standards Institution's Recommendations for Letter Symbols, Signs and Abbreviations deals with Electrical Science and Engineering (B.S. 1991: Part 6: 1963. Pp. 52. London: British Standards Institution, 1963. 12s. 6d. net). The recommendations are listed under three sections which are entitled: "General Principles", "Specific Usages" and "Indexes". The first outlines the principles for use in scientific and technological work. These aro intended, in particular, "for use in printed papers but they should be observed as far as possible in manuscript and typescript (with suitable instructions to the printer when necessary), and also by instructors in this work". This is all very well, but the section gives no indication to potential authors of how to signify to the printer details of case, type or font when writing by hand or using a normal typewriteran essential aspect for consistency of style. "Specific Usages" lists quantities and their symbols, units and their symbols, and abbreviations: a Greek alphabet is apponded. Section 3 is an alphabetical list of recommended symbols for physical quantities. An "Index of Words" is provided, also a short statement concerning the background, aims, objectivos and organization of the British Standards Institution.

\section{Inaugural Lectures at the Imperial College of Science and Technology}

THE acceptance of a chair in a university in Great Britain usually carries with it to-day the duty of the preparation and delivery of a public inaugural lecture at which the professor is formally introduced to the university and the wider public. Originally the inaugural lecture was morely the first lecture given by the professor in the ordinary course of his teaching duties. The text of the inaugural lecture is now printed and published. In addition, since the inaugural lectures at the Imperial College of Science and Technology, London, are all confined to scienco and technology, they can be combined in groups to be published in book form. The fourth volume in the series of Inaugural Lectures at Imperial College has recently been issued. It contains nine loctures covering the period of the two academic sessions $1960-61$ and 1961-62. They are: K. G. Denbigh (chemical ongineering science) on "The Science of Continuously Operating Systems"; $H$. Elliott (physics) on "Cosmic Rays and the Exploration of Space"; J. S. Rowlinson (chemical engineering) on "The Impact of Chemical Physics on Technology"; B. G. Neal (applied science with special reference to engineering) on "Some Problems in Plasticity"; B. J. Mason (cloud physies) on "The Physies of Clouds, Rain and Lightning"; M. H. Fleming (mineral technology) on "Mineral Technology-Progress and Problems"; J. H. Westcott (electrical engineering) on "A Prospect of Automatic Control"; W. D. Gill (oil technology) on "Geology in the Search of Oil"; and Sir Willis Jackson (electrical engineering) on "The Partnership betweon Science and Eleetrical Engineering".

\section{Man the Tool Maker}

Dr. OAKLEY is well known for his extensive research on Quaternary geology and carly prehistory. His work lies 